\title{
Financial Feasibility Study of Hydroponic Vegetables Business (A Case Study on Serua Farm, Kota Depok)
}

\author{
Farida Nursahib \\ \{farida.nursahib@gmail.com\}, Universitas Nasional, Jakarta, Indonesia
}

\section{Nurdin Brasit}

\{nurdinbrasit@gmail.com\},Faculty of Economics and Business,Hasanuddin University, Makassar, Indonesia.

\author{
Idrus Taba \\ \{emitaba71sa@gmail.com\}, Faculty of Economics and Business,Hasanuddin University, Makassar, Indonesia.
}

\section{Suharyono}

\{suharyono_unas@yahoo.com\}, Universitas Nasional, Jakarta, Indonesia

\begin{abstract}
Hydroponic, an agricultural cultivation technology, enabling farmers to plant more plants in a limited area. Therefore, it can be used to increase production, then gaining more profit. This study aimed to analyse production costs, incomes, break-even point , business efficiency, and financial feasibility of a hydroponic vegetable business. The method used in this study is direct interviews with the business owner, the head of the garden, the person in charge of the greenhouse and production and the person in charge of seeding. Serua Farm produces red spinach, green spinach, gai lan, and bok choy. The results show that the total production cost was Rp319,420,734 per hectare. Its profit was Rp. $688,579,266$ or $68,31 \%$ from gross incomes. R/C was 3.16 meant that the business efficiency was good. B/C was 2.16 meant that the business is profitable and financially feasible. NPV was Rp552,162,558 and IRR 107,5\%. PP value is five months six days.
\end{abstract}

Keywords:

Hydroponic, Vegetables, Cost, Incomes and Efficiency.

Article Received: 18 October 2020, Revised: 3 November 2020, Accepted: 24 December 2020

\section{Introduction}

\subsection{Background}

Vegetables are important commodities because they are needed in daily life and their demand continues increasing. Based on data from the Directorate General of Horticulture [1], vegetables production reach $10,871,224$ tons in 2011, 11,264972 tons in $2012,11,558,449$ tons in 2013, $11,918,571$ tons in 2014 , and $11,629,414$ tons in 2015. The data shows that the average vegetable production tends to increase every year.

Hydroponics is an agricultural cultivation technology that has the potential to be developed. This is due to the scarcity of land resources, mainly due to the development of the industrial and service sectors which has caused agricultural land to shift to non-agricultural land, so that conventional agricultural business activities are increasingly uncompetitive due to high land prices. Agricultural cultivation technology with a hydroponic system provides an alternative for farmers who have narrow land to carry out business activities that can be used as an adequate source of income [2].

In the last few years, vegetable industries that are different from conventional have emerged. One company that uses hydroponic vegetable cultivation methods is Kebun Serua Farm, which is located in the PT Nusa Bahana Abadi, Serua Village, Bojongsari District, Depok City.

Vegetables produced with hydroponic technology have better quality than conventional 
vegetables, but the costs required are higher. The target market segments are generally middle to upper economic circles. The high quality and special market segment make hydroponic vegetables can be sold at premium prices or much higher prices compared to conventional vegetable prices. Hydroponic vegetables are marketed to supermarkets, supermarkets, hotels and restaurants.

Hydroponic technology has many advantages, including saving land or space, saving fertilizer and water, being environmentally friendly, growing plants faster, quality of crop yields can be maintained, and quantity can be further increased. But the consequences, hydroponic vegetable business requires high costs in its production. The investment costs and operational costs required such as labour, the provision of irrigation facilities require a lot of costs, so the types of vegetables cultivated and the selling price of hydroponic vegetables are important to be considered by the hydroponic vegetable businessman. Analysis of costs and income of farming is one way to compare costs and income from production process activities. Farming is said to be successful if the farm can fulfil the obligation to pay for the tools used, labour costs and can maintain the sustainability of the business.

\subsection{Research Importance}

This research is expected to be useful information and description for hydroponic vegetable businesses in order to obtain an efficient and profitable business.

\subsection{Research Objective}

1. Analyzing the production costs and business income of hydroponic vegetable cultivation.

2. Analyzing the efficiency of hydroponic vegetable cultivation business.

3. Analyzing the financial feasibility of hydroponic vegetable cultivation business.

\subsection{Theoretical Review}

\subsubsection{Farming Business}

Farming is one of the activities of organizing agricultural production facilities and technology effectively and efficiently with the aim of getting maximum profit. Effective means that producers or farmers can make the best use of their resources, while efficiency means that the use of resources can later produce less output than inputs [3].

In accordance with its limitations, in every farming business, there is always an element of land or agricultural land that represents nature, there is an element of labour that relies on family members of farmers, and elements of capital of various kinds. The system of farming activities continues to develop over time and is very diverse in terms of productivity, the efficiency of land use, energy, and capital as well as its impact on the environment [4].

\subsubsection{Analysis of Farmer Business Income}

The goal of a farmer in running a farming business is to establish a combination in the branch of farming that can later provide maximum income because income has the function to meet daily needs and can provide satisfaction to farmers, so they can continue their activities [5].

Revenue is the difference between revenue and total costs used during the production process. Income in farming is divided into two, namely gross income and net income. Gross income is revenue that has not been reduced by production costs or what is usually referred to as revenue. Net income is revenue that has been reduced by production costs.

The amount of income received by farmers depends on the amount of revenue and expenditure during the production process. Revenue in farming is the total income received by producers from production activities that have been carried out or have generated money that has not been reduced by costs incurred during production. Revenue is obtained from the multiplication of production results with product selling prices [6]. 
The acceptance of farming is influenced by several factors, including the area of farming land, the amount of production, the type and price of the farming commodity cultivated. These factors are directly proportional, so if one of the factors has increased or decreased, it can affect the acceptance received by producers or farmers who do farming. The greater the area of land owned by farmers, the more production results will be so that the revenue that will be received by producers or farmers is greater.

\subsubsection{Analysis of Revenue on Costs ( $R / C$ Ratio)}

One indicator to determine eligibility in business is to calculate the $\mathrm{R} / \mathrm{C}$ ratio. Revenue to cost ratio shows how much revenue will be obtained from each rupiah spent in agricultural production. R/C Ratio is an analysis that is used to determine the benefits of farming means that the ratio of revenue to these costs can be known whether a farming business is profitable or not. $\mathrm{R} / \mathrm{C}$ Ratio can be sought by using a comparison between revenue and production costs incurred [7].

\subsubsection{Analysis of Benefit to Costs (B/C Ratio)}

Analysis of income over costs is a comparison between the level of profits or income obtained with the total costs incurred. A Business is said to be feasible and provides benefits if the $\mathrm{B} / \mathrm{C}$ ratio is greater than zero $(0)$, the greater the $\mathrm{B} / \mathrm{C}$ ratio value, the greater the benefits to be gained from the business [8].

\subsubsection{Break-Event Point}

Break-Event Point (BEP) is a break-event point where total revenue equals total cost. The breakevent point depends on the length of time a project's revenue flows can cover all operating and maintenance costs along with other capital costs. As long as the company is still below the BEP point, so long as the company is still suffering losses. The longer a company reaches breakeven, the greater the loss balance because the benefits received do not cover costs incurred [9].
In order to produce a product, it is necessary first to plan how much profit it wants to obtain. This means that profit is a priority that must be achieved, in addition to other things. In order for profit to be easily determined, one way is to know in advance what the value of the BEP is. BEP analysis is a technique to find out the relationship between production volume, sales volume, selling price, production costs, variable and fixed costs, and profit and loss [10].

\subsubsection{Hydroponic System}

Hydroponics is the cultivation of plants by utilizing water as a growing medium by emphasizing the fulfilment of nutritional needs for plants. Generally, the planting media used in hydroponics are a shaft, such as sand, husk charcoal, pumice, gravel, and rock wool.

The most prominent engineering of environmental factors in hydroponics is in the provision of nutrients needed by plants in the right amount and easily absorbed by plants. In order to meet the needs of sunlight and air humidity needed by plants during their growing period, we build a greenhouse that serves to regulate the temperature and humidity of the air in accordance with the needs of plants.

Hydroponically grown plants are healthier because they receive balanced nutrition, and spend less energy in finding water and nutrients. As a result, hydroponic crop production is generally crisper and fresher than crop production using soil.

Nutrient Film Technique (NFT) is a hydroponic technique by thinly channelling nutrient water and continuously passing through plant roots, so that plant roots will always get optimal water intake, nutrition, and oxygen supply [11]. The part of the roots exposed to water will absorb nutrients, while the upper roots will more easily absorb oxygen to meet the needs of plant growth. See figure 1 [12]. 


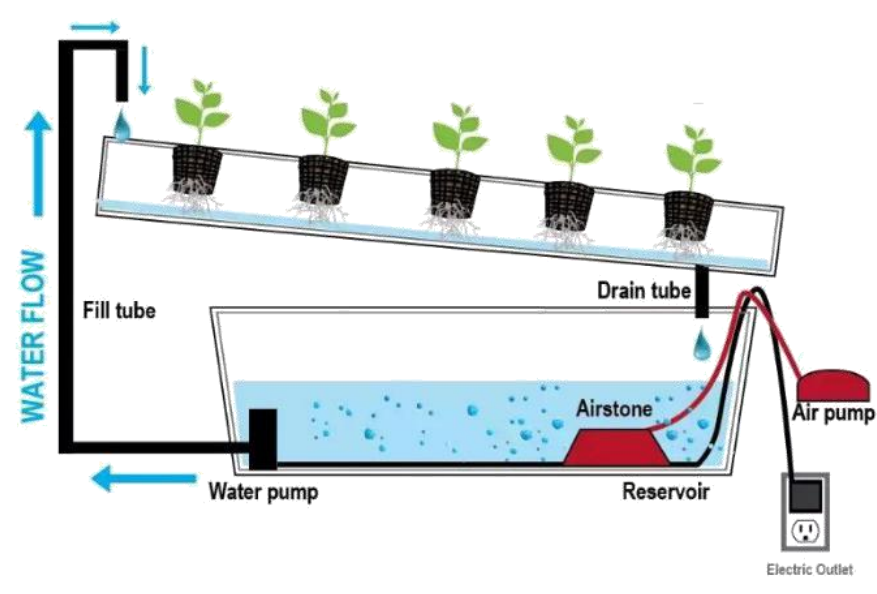

Fig. 1.NFT Hydroponic System

Requirements needed for plant growth by the NFTmethod are as follows:

a. Uniformity of chamfer slope where nutrient solution flows downward.

b. The speed of flow of nutrients must not be too fast.

c. Gutter width is sufficient to prevent the flow of nutrients by the collection of roots.

d. The base of the chamfer must be flat and not curved.

Some of the advantages of using the NFT method are:

1. Make it easier for plant roots to reach water media.

2. Water and nutrients are available on a continuous basis.

3. Nutrition needs can be adjusted to the age and type of plants.

4. Can be planted several times without changing installation equipment.

The weaknesses of the NFT method are:

1. High initial investment

2. Expensive maintenance costs

In terms of cost, $\mathrm{AB}$ mix nutrition has a relatively higher price because the use and purchase of $\mathrm{AB}$ mix nutrition must be one package. The nutrient content of $\mathrm{AB}$ mix has a balanced composition needed by plants. The balanced nutrient composition in question is the content of macro and micronutrients needed by plants already contained in the $\mathrm{AB}$ mix nutrient solution and the nutrients obtained by plants from the $\mathrm{AB}$ mix nutrient solution have met the needs of plants.

The quality of the nutrient solution will determine the success of NFT hydroponics, while the quality of the nutrient depends on its concentration. If the concentration does not match the type or age of the plant, the production will be disappointing. Nutrient concentration of NFT needs to be known because all food needs for plants are supplied from this solution. Some types of plants that can be planted hydroponically are lettuce, celery, tomatoes, cucumbers, mustard greens, spinach, you, bok choy and chilli.

\section{Research Methodology}

This study was conducted in 2018 at the Serua Farm hydroponic garden located on Jalan Serua Raya Warehouse Complex PT. Nusa Bahana Abadi, Serua Village, Bojongsari District, Depok City.

\subsection{Data Collection}

The types of data in this study are primary data and secondary data. Primary data were obtained by conducting direct observations in the field and through direct interviews with the business owner, the head of the garden, the person in charge of the greenhouse and production and the person in charge of seeding. Secondary data is supplementary data from primary data sourced from relevant literature. Secondary data collected is data from relevant agencies such as the Directorate General of Horticulture. In addition, internet searches were also carried out in the form of journals, supporting books and kinds of literature related to this study.

\subsection{Data Analysis}

Data processing methods are carried out using qualitative and quantitative methods. The qualitative method is used to describe the Serua Farm's hydroponic vegetable business. Quantitative methods carried out include analysis of costs, incomes, profits, and efficiency using the 
ratio of return to costs ( $\mathrm{R} / \mathrm{C}$ Ratio), ratio of benefit to costs (B / C Ratio), and calculation of break event points (BEP). We also used the investment criteria analysisto find out whether this business is feasible or not.

\subsubsection{Production Costs}

Production costs were calculated according to this equation:

$\mathrm{TC}=\mathrm{FC}+\mathrm{VC}$

$\mathrm{TC}=$ Total costs $(\mathrm{Rp} /$ year $)$

$\mathrm{FC}=$ Fixed costs $(\mathrm{Rp} / \mathrm{year})$

$\mathrm{VC}=$ Variable costs (Rp/year)

Calculation of depreciation of agricultural equipment basically starts at the purchase price until the tools provide benefits. Depreciation value in this study is calculated based on the straightline method.

\subsubsection{Returns/Revenue}

Returns of agricultural business calculated by multiplying the amount of production and the selling price

$$
\mathrm{TR}=\mathrm{y}+\mathrm{Py}
$$

$\mathrm{TR}=$ Total returns $(\mathrm{Rp} / \mathrm{year})$

$\mathrm{y}=$ Total amount of agricultural production (kg/year)

$\mathrm{Py}=$ Selling price of the products $(\mathrm{Rp} / \mathrm{kg})$

\subsubsection{Incomes/Benefit}

Incomes were calculated according to this equation:

$$
\mathrm{I}=\mathrm{TR}-\mathrm{TC}
$$

$\mathrm{I}=$ Incomes $(\mathrm{Rp} /$ year $)$

$\mathrm{TR}=$ Total returns $(\mathrm{Rp} /$ year $)$

$\mathrm{TC}=$ Total costs $(\mathrm{Rp} / \mathrm{year})$

\subsubsection{Return to Cost Ratio}

$\mathrm{R} / \mathrm{C}$ ratio describes the business efficiency by comparing its total revenue to total costs.

$$
\mathrm{R} / \mathrm{C} \text { ratio }=\frac{\mathrm{TR}}{\mathrm{TC}}
$$

$$
\begin{aligned}
& \mathrm{TR}=\text { Total returns }(\mathrm{Rp} / \text { year }) \\
& \mathrm{TC}=\text { Total costs }(\mathrm{Rp} / \text { year })
\end{aligned}
$$

\subsubsection{The Benefit to Cost Ratio}

$\mathrm{B} / \mathrm{C}$ ratio describes the business feasibility by comparing its total incomes to total costs.

$$
\mathrm{B} / \mathrm{C} \text { ratio }=\frac{\mathrm{I}}{\mathrm{TC}}
$$

$$
\begin{aligned}
& \mathrm{I}=\text { Incomes }(\mathrm{Rp} / \text { year }) \\
& \mathrm{TC}=\text { Total costs }(\mathrm{Rp} / \text { year })
\end{aligned}
$$

\subsubsection{Break Event Point}

BEP used to find out the minimal amount of sales needed to gain total returns exactly as much as total costs. At this point, the business does not get benefits nor loss.

$$
\mathrm{BEP}(\mathrm{Q})=\frac{\mathrm{FC}}{\mathrm{P}-\mathrm{VC}}
$$

$$
\begin{aligned}
& \mathrm{P}=\text { Price }(\mathrm{Rp} / \text { year }) \\
& \mathrm{VC}=\text { Variable costs }(\mathrm{Rp} / \mathrm{year}) \\
& \mathrm{FC}=\text { Fixed costs }(\mathrm{Rp} / \text { year })
\end{aligned}
$$

\section{Result and Discussion}

\subsection{About Serua Farm}

Serua Farm is the main garden in the hydroponic business unit of the C.V.Usaha KreasiMadani. In 2014, the company consisted of 
several business units, one of which was named Hidroponikita. The Hidroponikita business unit is engaged in hydroponic plant cultivation, hydroponic training, and hydroponic garden installation manufacturing services.

In2017, a hydroponic vegetable cultivation business carried out with an area of $1,000 \mathrm{~m}^{2}$. The cultivation system used at Serua Farm is the Nutrient Film Technique (NFT). In this system, the roots grow in a very shallow and circulating nutrient solution. Some roots are in the air space in the channel to absorb oxygen, and some others are submerged in nutrient solution so that they can absorb the nutrients needed by plants. Serua Farm cultivates four vegetable commodities: red spinach, green spinach, gai lan, and bokchoy.

\subsection{Financial Data}

The Calculation of production costs, total revenue/returns, and total incomesof Serua Farm are described in the following table 1.

Table 1.Production costs, total revenue/returns, and total incomes per hectares.

\begin{tabular}{lrr}
\hline & Amount (Rp) & Percentage (\%) \\
A. Fixed Costs & & \\
1. Rent of $10.000 \mathrm{~m}^{2}$ land & 6.000 .000 & 1,90 \\
2. Depreciation of buildings and equipments & 47.617 .500 & 14,91 \\
3. Employee honorarium & 63.000 .000 & 19,72 \\
Total Fixed Costs (FC) & 116.617 .500 & 36,53 \\
B. Variable Costs & & \\
1. Seeds & 10.729 .384 & 3,36 \\
2. Pesticide & 5.100 .400 & 1,60 \\
3. Nutrition AB mix & 65.010 .000 & 20,35 \\
4. Rockwool & 72.637 .500 & 22,74 \\
5. Seedbed plastic & 157.500 & 0,05 \\
6. Packaging & 8.304 .000 & 2.60 \\
7. Dish-washing soap & 449.850 & 0,14 \\
8. Pests trap & 3.014 .600 & 0,94 \\
9. LPG & 1.400 .000 & 0,43 \\
10. Electricity & 36.000 .000 & 11,27 \\
Total Variable Costs (VC) & 202.803 .234 & 63,47 \\
Total Production Costs (PC) & 319.420 .734 & 100,00 \\
C. Revenue/Returns(R) & & \\
(57.600 Kg x Rp. 17.500) & 1.008 .000 .000 & \\
D. Incomes/Benefit (I or B) & & \\
(Rp. 1.008.000.000 - Rp. 319.420.734) & 688.579 .266 & \\
\hline
\end{tabular}

\subsection{Financial Analysis}

\section{R/C Ratio}

$\mathrm{R} / \mathrm{C}$ ratio at 3.16 means the hydroponic vegetable cultivation business has been efficient. This is in line with Panjaitan et al. (2014) which states that if the $\mathrm{R} / \mathrm{C}$ ratio value is greater than one, the business is efficient. See table 2.

\section{Amount (Rp)}

Total

Returns $\quad 1.008 .000 .000$

Total Costs 319.420 .734

R/C Ratio 3,16

\section{B/C Ratio}

Table 2.Return to Cost Ratio of Serua Farm 
The $\mathrm{B} / \mathrm{C}$ ratio at 2.16 means that the hydroponic vegetable cultivation business provides benefits and is worth the effort. This is in line with Soekartawi (2013) which states that if the $\mathrm{B} / \mathrm{C}$ ratio value is greater than zero, then the business that is run has a profit. See table 3 .

Table 3.The Benefit to Cost Ratio of Serua Farm

\begin{tabular}{ll}
\hline & Amount (Rp) \\
Incomes & 688.579 .266 \\
Total Costs & 319.420 .734 \\
B/C Ratio & 2,16 \\
\hline
\end{tabular}

\section{Break-Event Point (BEP)}

Fixed costs of Rp. 116,617,500, - per unit, the selling price of $\mathrm{Rp} 17,500$, and variable costs per unit of Rp. 3,521. BEP calculated of $18,252 \mathrm{~kg}$ annually. It means the business will get benefit/profit if it sells more than $18,252 \mathrm{~kg}$ per year. See table 4.
Table 4. Break-Event Point of Serua Farm

Amount (Rp)

Total Fixed Costs $\quad 116.617 .500$

Variable Costs per Unit 3.521

Selling Price per Unit $\quad 17.500$

BEP

$18.252(\mathrm{~kg} /$ year $)$

\section{Investment Criteria Analysis}

Net Present Value (NPV) of Rp552,162,558 is greater than zero means that the cultivation of vegetables in a hydroponic business is feasible from the financial aspect. The IRR value of $107.5 \%$ is greater than the current interest rate, and this also shows that this business is feasible to run. The Payback Period value of 5 months 16 days is much faster than the economic value of investment (3 years). See table 5.

Table 5.The Investment Criteria Analysis

\begin{tabular}{llllll}
\hline Year & Benefit & Cost & Net Benefit & DF (15\%) & NPV 15\% \\
0 & 0 & 319.420 .734 & -319.420 .734 & 1,000 & -319.420 .734 \\
1 & 688.579 .266 & 319.420 .734 & 369.158 .532 & 0,885 & 326.705 .300 \\
2 & 688.579 .266 & 319.420 .734 & 369.158 .532 & 0,783 & 289.051 .130 \\
3 & 688.579 .266 & 319.420 .734 & 369.158 .532 & 0,693 & $255,826.862$ \\
Amount & 2.065 .737 .798 & 1.277 .682 .936 & 788.054 .862$. & & 552.162 .558 \\
\hline
\end{tabular}

\section{Conclusion}

The total production cost for hydroponic vegetable production is $\mathrm{Rp} 319,420,734$ per hectare. The amount of income is Rp688,579,266 or $68.31 \%$ of the value of revenue. $\mathrm{R} / \mathrm{C}$ ratio is 3.16, which means the hydroponic vegetable cultivation business is efficient. While the $\mathrm{B} / \mathrm{C}$ ratio is 2.16 , which means that the hydroponic vegetable cultivation business provides benefits and is worth the effort. NPV value of Rp552,162,558 or greater than zero means that the cultivation of vegetables in a hydroponic way is worth the effort from the financial aspect. The IRR value of $107.5 \%$ is greater than the current interest rate, and this also shows that this business is feasible to run. The Payback Period value of 5 months 16 days is much faster than the economic value of investment (3 years).

\section{References}

[1] Directorate General of Horticulture. : Statistik Produksi Hortikultura. Kementrian Pertanian RI, Jakarta. (2016)

[2] Roidah, I. S. : Pemanfaatan Lahan dengan Menggunakan Sistem Hidroponik. Jurnal Univesitas Tulungagung Bonorowo 1 (2) : 43-50 (2014)

[3] Fauzan, M. : Pendapatan, Risiko, dan Efisiensi Ekonomi Usaha Tani Bawang Merah di Kabupaten Bantul. Jurnal Agraris 2 (2) : $105-117$ (2016) 
[4] Luntungan, A. Y. : Analisis Tingkat Pendapatan Usaha Tani Tomat Apel di Kecamatan Tompaso Kabupaten Minahasa. Jurnal Pembangunan Ekonimi dan Keuangan Daerah 7 (3) : 1-25(2012)

[5] Murniati, K., J. Handoyo Mulyo., Irham, dan S. Hartono : Efisiensi Teknis Usaha Tani Padi Organik Lahan Sawah Tadah Hujan di Kabupaten Tanggamus Provinsi Lampung. Jurnal Penelitian Pertanian Terapan 14 (1) : 31 - 38 (2014)

[6] Ambarsari, W., Ismadi, dan A. Setiadi : Analisis Pendapatan dan Profitabilitas Usaha Tani Padi (Oryza sativa L.) di Kabupaten Indramayu. Jurnal Agri Wiralodra 6 (2) : 19-27 (2014)

[7] Panjaitan, F. E. D., S. N. Lubis, dan Hasim : Analisis Efisiensi Produksi dan Pendapatan Jagung (Studi Kasus Desa Kuala, Kecamatan Tigabinaga, Kabupaten Karo). Jurnal Sosial Ekonomi Agribisnis 3 (3) : 1-14(2014)

[8] Soekartawi : Agribisnis. Raja Grafindo Persada : Jakarta (2013)

[9] Zikri, A. R. : Analisis Usaha dan Pemasaran Jamur Tiram Putih (Pleurotus ostreatus) Studi Kasus di Kelurahan Tangkerang Timur Kecamatan Tenayan Raya Kota Pekanbaru. Jurnal Online Mahasiswa Fakultas Pertanian Universitas Riau 2 (2) : 1- 10 (2015)

[10] Kasmir : Analisis Laporan Keuangan. Raja Grafindo Persada: Jakarta (2016)

[11] Mubarok, S., A. Albi Fauzi, Anas dan Nursuhud : Peningkatan Pemahaman dan Ketertarikan Masyarakat Arjasari terhadap Teknik Budidaya Tanaman Tomat Melalui Metode Nutrient Film Technique (NFT). Jurnal Aplikasi Teknik dan Pengabdian Masyarakat 2 (1) : 9-12 (2018) 